\title{
RANCANG BANGUN SISTEM INFORMASI AKADEMIK PADA SEKOLAH TINGGI TEOLOGI MORIAH
}

\author{
Ricki Sastra[1], Imam Nawawi[ ${ }^{[2]}$, Numan Musyaffa[3] \\ Program Studi Teknologi Komputer,Universitas Bina Sarana Informatika[1] \\ Program Studi Sistem Informasi, Universitas Bina Sarana Informatika ${ }^{[2]}$ \\ Program Studi Sistem Informasi,STMIK NusaMandiri ${ }^{[3]}$ \\ Jl.Kramat Raya No.98 .Jakarta Pusat ${ }^{[1][2]}$ \\ JI. Damai No. 8, Warung Jati Barat[3] \\ ricki.rkt@bsi.ac.id[1],imam.imw@bsi.ac.id[2],numan.mnf@nusamandiri.ac.id[3]
}

\begin{abstract}
Information technology is developing so rapidly from day to day. With the development of information technology a lot of easiness given in conveying a precise and accurate information. Computers and the Internet is one means of information techncontinues to evolve rapidly and never-ending. so the student and lectures will be much easier and more efficient in having the data of the schedule, scoring and other information that is needed. It will also help them to work faster and more accurate rather than taking notes for every information that they need. With web-based information systems academic is expected to provide a solution as a problem solver above. So as to facilitate academic activities in obtaining more accurate information without needing alot of timeand energy iswasted.
\end{abstract}

Keywords : Internet, Information Systems Academic School.

Intisari-Teknologi informasi berkembang begitu cepat dari hari ke hari. Dampak positif dari perkembangan teknologi informasi banyak sekali kemudahan-kemudahan yang diberikan dalam menyampaikan sebuah informasi yang tepat dan akurat. Komputer dan internet merupakan salah satu sarana teknologi informasi yang terus berkembang dengan cepat dan tidak akan pernah ada habisnya. penambahan data mahasiswa, data dosen, dan data nilai mahasiswa-mahasiwi, STT Moriah masih menggunakan buku catatan sehingga relatif lama dan kurang efektif. Dengan dibangunnya sistem informasi akademik berbasis web ini diharapkan dapat memberikan solusi sebagai pemecah masalah diatas. Sehingga dapat mempermudah aktifitas akademik dalam memperoleh informasi yang lebih akurat tanpa perlu banyak waktu dan tenaga yang terbuang.
Kata Kunci : internet, sistem informasi akademik sekolah

\section{PENDAHULUAN}

Perkembangan teknologi yang semakin maju di era globalisasi seperti sekarang ini menuntut sumber daya manusia yang berkualitas dalam hal komputerisasi bagi semua kalangan, baik dari segi pendidikan maupun dalam dunia bisnis. Saat ini komputer juga dapat digunakan sebagai pengolahan data dalam dunia pendidikan, kesehatan, pemerintah, atau swasta.

Kebutuhan informasi dalam dunia pendidikan menjadi sangat penting dalam menentukan kemajuan suatu lembaga. Dengan pemanfaatan dan penerapan teknologi informasi, kumpulan data yang saling berhubungan satu sama lain dapat diorganisasikan menjadi sebuah file basis data, dimana data-data diorganisasikan kemudian disimpan kedalam komputer untuk memudahkan pemakai dalam mengakses informasi.

Sekolah Tinggi Teologi (STT) Moriah Tangerang adalah salah satu sekolah tinggi yang masih menerapkan sistem konvensional dalam pelayanan. Baik kepada tenaga pengajar atau dosen, staff maupun kepada mahasiswanya. sistem ini dirasakan oleh para pengguna informasi di sekolah tinggi tersebut kurang efektif dan efisien karena dalam pengolahan data mahasiswa berupa KHS dan transkrip akademik, data dosen, pembuatan nilai, pembuatan jadwal perkuliahan yang masih menggunakan buku catatan yang mana dalam proses pencatatannya membutuhkan waktu yang relatif lama, belum ada sistem validasi data, dan terkadang terjadi kehilangan data. hal ini terjadi seperti di penelitian sebelumnya yaitu yang dilakukan oleh (Nuraini, Purnama, \& Tj, 2013) Pada Program Studi Teknik Informatika Universitas Surakarta, terdapat kekurangan dalam pengisian KRS karena masih bersifat konvensional. Mengharuskan mahasiswa datang ke kampus, mengambil formulir KRS dan 
mahasiswa mengisinya secara manual. Hal ini menjadi kurang efektif dan efiesien. Dengan permasalahan yang ada,maka perlu untuk membuat suatu sistem informasi KRS dan KHS yang dibangun dengan menggunakan bahasa pemrograman PHP dan menggunakan database MySQL. Dengan sitem informasi KRS dan KHS, maka hasilnya adalah memudahkan kinerja admin dalam pengolahan data KRS dan KHS. Mahasiswa tidak datang ke kampus untuk mengambil formulir KRS. Sehingga proses KRS dan KHS lebih efektif dan efisien. Dari sini peneliti melakukan penelitian untuk membuat sistem informasi akademik tentang pengolahan data mahasiswa, data dosen dan pembuatan nilai, pembuatan jadwal perkuliahan sehingga prosesnya diharapkan relatif efektif dan efisien.

Solusi untuk mengatasi masalah yang ada pada STT Moriah, penulis akan menerapkan konsep dasar system informasi yang memudahkan bagi setiap pelaku yang terlibat di STT Moriah. Menurut (Sutabri, 2012) yang dimaksud degan konsep dasar sistem adalah suatu kumpulan atau himpunan dari unsur, komponen, atau variable yang terorganisasi, saling berinteraksi, saling tergantung satu sama lain, dan terpadu.

Agar system informasi yang akan dibangun ini menjadi bermanfaat dan tepat sasaran, maka peneliti membuat rancangan terlebih dahulu, mulai dari Unified Modeling Language, Use Case diagram, activity Diagram, Component Diagram, Deployment Diagram, entity Relationship diagram. Peneliti juga membandingkan degan mengkomparasai dengan penelitian-penelitian yang sudah dilakukan sebelumnya dengan kasus yang sama.

Menurut Nugroho dalam (Nawawi, Abdilah, \& Nurajijah, 2018) Unified Modeling Language (UML) adalah bahasa pemodelan sistem atau perangkat lunak yang berparadigma berorientasi objek.

Menurut (Rosa A. S \& Shalahudin, 2014) diagram UML (Unifield Modeling Language) memiliki jenis-jenis yaitu : Use case atau diagram use case merupakan pemodelan untuk melakukan (behavior) sistem informasi yang akan dibuat. Use case mendeskripsikan sebuah interaksi antara satu atau lebih aktor dengan sistem informasi yang akan dibuat. Diagram aktivitas atau activity diagram menggambarkan workflow (aliran kerja) atau aktivitas dari sebuah sistem atau proses bisnis. Yang perlu diperhatikan disini adalah bahwa diagram aktivitas menggambarkan aktivitas sistem bukan apa yang dilakukan aktor, jadi aktivitas yang dapat dilakukan oleh sistem. Diagram komponen atau Component Diagram dibuat untuk menunjukkan organisasi dan ketergantungan diantara kumpulan komponen dalam sebuah sistem. Diagram komponen fokus pada komponen sistem yang dibutuhkan dan ada di dalam sistem. Diagram Deployment atau deployment diagram menunjukan konfigurasi komponen dalam proses eksekusi aplikasi.

Menurut (Fathansyah, 2012) Model Entity-Relationship yang berisi kompenenkomponen Himpunan Entitas dan Himpunan Relasi yang masing-masing dilengkapi dengan atribut-atribut yang mempresentasikan seluruh fakta dari 'dunia nyata' yang kita tinjau, dapat digambarkan dengan lebih sistematis dengan menggunakan Diagram Entity-Relationship (Diagram E-R).

Menurut Wahana dalam penelitian yang dilakukan oleh (Mahfudz, 2013) "PHP merupakan bahasa pemrograman yang digunakan untuk membuat program website dimana kode program yang telah dibuat dikompilasi dan dijalankan pada sisi server untuk menghasilkan halaman website yang dinamis".

Menurut Madcoms penelitian yang dilakukan oleh (Mahfudz, 2013) "PHP adalah sebuah bahasa scripting yang terpasang pada HTML. Sebagian besar sintaksnya mirip dengan bahasa pemograman C, Java, Asp dan Perl, ditambah beberapa fungsi PHP yang spesifik dan mudah dimengerti".

Menurut (Kadir, 2009) MySQL merupakan software yang tergolong database server dan bersifat Open Source menyatakan bahwa software ini dilengkapi dengan source code (kode yang dipakai untuk membuat MySQL), selain tentu saja bentuk executable-nya atau kode yang dapat dijalankan secara langsung dalam sistem operasi dan bisa diperoleh dengan cara mengunduh di internet secara gratis.

(Liatmaja \& Wardati, 2013) Semua sistem informasi akademik di Be Excellent Pacitan masih dilakukan secara konvensional, kesalahan pencatatan data akademik dan komunikasi antar pengelola akademik masih kurang berjalan baik. Selain itu siswa didik harus datang ke tempat les untuk mengetahui informasi akademik dan bagian administrator masih harus mencari data yang diinginkan siswa didik secara konvensional yang membutuhkan waktu cukup lama. Untuk itu, pada penelitian ini penulis membuat Sistem Informasi Akademik Berbasis Web pada Be Excellent Pacitan, diharapkan mampu memberikan kecepatan dan keakuratan dalam melakukan penyajian dan pelaporan informasi akademik. 
Pada penelitian yang dilakukan oleh (Kesuma \& Rahmawati, 2017) bahwa Pada SMK Purnama 2 Banyumas. Sekolah ini masih menggunakan sistem yang manual dalam pengolahan data akademik dengan memanfaatkan Microsoft Excel, Microsoft Word, dan pencatatan dengan media kertas sehingga proses kerjanya cukup rumit dan kebutuhan akan kertas serta ruang penyimpanannya cukup besar. Hal ini dapat beresiko terjadinya kerusakan data fisik, kerangkapan data dan kehilangan data. Proses penyampaian informasi juga menjadi lebih lambat sebab siswa hanya dapat memperoleh informasi ketika berada di sekolah serta hanya dapat melihat nilai akhir melalui rapot

Berdasarkan masalah yang ada di STT Moriah Tangerang, maka untuk memberikan solusi dari masalah yang dihadapi, peneliti merumuskan bagaimana membuat sebuah aplikasi sistem informasi akademik berbasis web yang dapat digunakan dan dimanfaatkan oleh STT Moriah Tangerang untuk dapat mempermudah dan mempercepat dalam pengolahan data mahasiswa, data dosen dan pembuatan nila, serta dapat mengurangi resiko kehilangan data. selain itu juga dapat memudahkan mahasiswa dan mahasiswi dalam mendapatkan laporan nilai semester dalam bentuk Kartu Hasil Studi (KHS) dan transkip akademik.

Dari hasil penelitian ini, peneliti mempunyai tujuan agar sistem informasi akademik ini dapat menjadi referensi bagi para peneliti-peneliti yang akan datang.

\section{BAHAN DAN METODE}

\section{Rancangan Penelitian}

Rancangan penelitian yang digunakan pada penelitian ini adalah deskriptif kualitatif yang bersifat menggambarkan, memaparkan dan menguraikan objek yang diteliti. Peneliti bermaksud membuat deskripsi atau gambaran untuk memahami prosedur-prosedur yang harus dilakukan oleh pelaku-pelaku yang menggunakan sistem informasi ini atau fenomena yang dialamai oleh peneliti yang berupa proses menambahkan data baru dari data mahasiswa, menambahkan data baru dari data dosen atau data tenaga pengajar, proses dalam merancang dan membuat jadwal perkuliahan, membuat rekapitulasi pencatatan nilai sampai dengan pembuatan Kartu Rencana Studi (KRS) sebagai daftar studi yang harus diikuti oleh mahasiswa, Kartu Hasil Studi (KHS) sebagai bukti keikutsertaan mahasiswa serta Transkip akademik yang berisi nilai-nilai matakuliah.
Metode ini digunakan sesuai dengan tujuan yaitu mengkaji penelitian secara alamiah. Dalam penelitian ini peneliti mengamati tiap proses yang terjadi.

\section{Sumber Data}

Sumber data pada penelitian ini adalah responden yang peneliti wawancari, proses penambahan, pengubahan, pencarian dan penghapusan data mahasiswa, dosen, jadwal perkuliahan, dan data pemberian nilai, serta proses pembuatan KRS, KHS dan Transkip akademik.

Dalam proses wawancara. Peneliti mewawancari responden yaitu Rektor Sekolah Tinggi Teologi Moriah Tangerang. Proses penambahan, pengubahan, pencarian hingga penghapusan data baik data mahasiswa, dosen, matakuliah, maupun nilai dilakukan dengan cara mencatat di buku catatan dengan masingmasing membutuhkan waktu yang berbedabeda.

\section{Teknik Pengumpulan Data}

Peneliti memperoleh data dengan melakaukan riset secara langsung kepada sekolah terkait dalam prosedur yang sistematik dan standar sehingga mendapatkan data-data yang baik dan benar dengan model pengumpulan data sebagai berikut:

\section{Observasi}

Dalam hal ini peneliti melakukan observasi atau pengamatan secara langsung ke kampus Sekolah Tinggi Teologi Moriah melalui Puket I Bidang Akademik untuk mempelajari, mengamati, dan mengumpulkan data serta informasi yang digunakan dalam kegiatan akademik di dalam sistem yang sedang berjalan.

\section{Wawancara}

Dalam hal ini peneliti melakukan wawancara untuk melengkapi bahan yang sudah ada selama observasi. Peneliti melakukan wawancara kepada Rektor Sekolah Tinggi Teologi Moriah Tangerang.

3. Studi Pustaka

Peneliti melakukan penelitian kepustakaan untuk memperoleh aspek-aspek teoritis dalam pengumpulan dokumen seperti jurnal, modul, dan buku yang berhubungan dengan masalah yang ditinjau dalam penyusunan penelitian ini.

\section{Model Pengembangan Sistem}

\section{Analisa Kebutuhan Software}

Aplikasi yang digunakan dalam pengembangan Sistem Informasi Akademik (SIAK) adalah aplikasi berbasis web (web- 
base application) yang dapat diakses baik melalui jaringan LAN maupun internet. Pembuatan Sistem Informasi Akademik (SIAK) menggunakan web server xampp, bahasa script PHP, dan MySQL sebagai database-nya. Pengembangan Sistem Informasi Akademik (SIAK) tidak membahas keamanan data secara terinci. Pengembangan Sistem Informasi Akademik (SIAK) tidak dilakukannya tahap mengoperasikan sistem informasi pada tahap implementasi sistem, melainkan hanya dilakukan tahap membangun, menginstall, dan menguji sistem informasi. Informasi yang akan dihasilkan adalah informasi data mahasiswa dan mahasiswi, informasi data dosen, informasi data nilai, informasi kalender akademik dan informasi data KHS. Pengisian data nilai secara online yang dilakukan oleh dosen. Peneliti melakukan analisa terhadap software yang akan dibuat pada sistem informasi akademik dimulai dari login dan di dalamnya terdapat 3 menu login yang pertama login admin, lalu login dosen, dan login mahasiswa dan mahasiswi yang mana fungsinya berbeda-beda. Login admin berfungsi untuk menginput data nilai, data transkrip akademik, lalu menginput data dan informasi akademik lainnya, dan menginput biodata dosen dan mahasiswa dan mahasiswi. Login Dosen untuk melihat data dan informasi akademik, biodata dosen, dan melihat daftar mahasiswa dan mahasiswi. Sedangkan Login mahasiswa dan mahasiswi berfungsi untuk melihat informasi akademik, melihat biodata mahasiswa dan mahasiswi, dan melihat laporan nilai berupa KHS dan transkrip akademik. Pada form profile berfungsi untuk memberitahukan kepada mahasiswa dan mahasiswi dan dosen tentang profil lengkap kampus. Dan pada form Help merupakan menu untuk melihat panduan dan bantuan dalam penggunaan aplikasi Sistem Informasi Akademik (SIAK).

\section{Desain}

Pada tahap ini, Peneliti mulai memikirkan perancangan program yang akan dikerjakan, dengan acuan program yang dibuat harus user friendly dan dengan menggunakan metode UML (Unified Modeling Language) dengan membuat Use Case Diagram, Activity Diagram, Component Diagram dan Deployment Diagram lalu desain database menggunakan ERD.

\section{Code Generation}

Dalam pembuatan aplikasi akademik pada Sekolah Tinggi Teologi Moriah Tangerang ini. Peneliti menggunakan konsep pemrograman yang terstruktur dan bahasa script yang digunakan adalah PHP.

\section{Pengujian}

Pada tahapan ini proses pengujian yang akan dilakukan menggunakan black box testing.

\section{Support}

Membangun sistem informasi akademik ini peneliti menggunakan perangkat pendukung. Seperti software dan hardware. Software yang digunakan yaitu web server, browser, diagram designer, Dalam pembahasan ini peneliti menggunakan hardware pendukung sebuah notebook dengan processor core (TM) i3-2310M CPU @ $2.10 \mathrm{GHz} 2.10 \mathrm{GHz}$ RAM (Random Access Memory) 2.00GB, dan Hard Disk 1,85 GB. Lalu peneliti juga akan mempublikasikan sistem informasi akademik pada salah satu penyedia layanan web hosting agar sistem ini bisa diakses kapan pun dan dimanapun user berada.

\section{HASIL DAN PEMBAHASAN}

Penelitian yang dilakukan oleh (Nuraini et al., 2013) yaitu berkaintan dengan pengelolaan KRS dan KHS yang masih konvensional yaitu dengan cara mengisi manual dengan mahasiswa harus datang ke kampus untuk bisa mengisi. Kemudian dibuatkan sistem informasi KRS dan KHS dengan mengadopsi jaringan internet.

\section{Tinjauan Institusi}

Sekolah Tinggi Teologi Moriah Tangerang adalah lembaga pendidikan dari Moriah yang didirikan sejak tahun 2007. Pendiri STT Moriah adalah: Almarhum Bapak Handiman Tjokrosaputro.

Sekolah Tinggi Teologi Moriah memiliki dua program jurusan yaitu S.Th (Sarjana Theologi) dan S.Pd.K (Sarjana Pendidikan Kristen).

\section{Analisis Kebutuhan Software Tahapan Analisis}

Sistem informasi akademik berbasis web dimana mahasiswa dan dosen tidak bertatap muka secara langsung. Mahasiswa dapat melihat informasi seperti nilai, dan kegiatan akademik 
lainnya melalaui media browser. Berikut ini spesifikasi kebutuhan (system requirement) dari sistem informasi akademik.

Halaman Mahasiswa:

1. Mahasiswa dapat login berdasarkan nim dan password.

2. A2. Mahasiswa dapat melihat data diri mahasiswa.

3. A3. Mahasiswa dapat melihat data dosen.

4. A4. Mahasiswa dapat melihat data nilai.

5. A5. Mahasiswa dapat melihat dan mencetak KHS.

6. A6. Mahasiswa dapat melihat data mata kuliah.

Halaman Dosen:

1. Dosen dapat login berdasarkan nid dan password.

2. Dosen dapat melihat data diri dosen.

3. Dosen dapat melihat data mahasiswa.

4. Dosen dapat menginput nilai.

Halaman Admin:

1. Admin dapat mengelola data mahasiswa.

2. Admin dapat mengelola data dosen.

3. Admin dapat mengelola data admin.

4. Admin dapat mengelola mata kuliah.

5. Admin dapat mengelola data nilai.

6. Admin mengelola data KHS.

Dalam membangun sistem onformasi akademik pada Sekolah Tinggi Teologi Moriah, peneliti membuat rancangan sistem terlebih dahulu. Yaitu pertama peneliti membuat rancangan diagram use case. Use case diagram yang dirancangan adalah sebagai berikut:

\section{Use Case Diagram Halaman Mahasiswa}

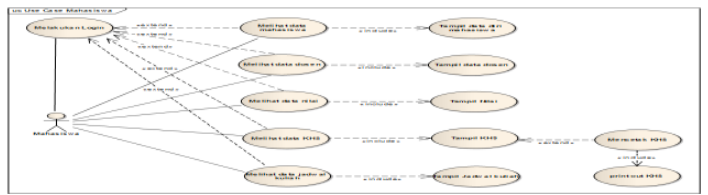

Sumber: (Sastra, Nawawi, \& Abdilah, 2019) Gambar 1. Use Case Diagram Halaman Mahasiswa

Gambar di atas menjelaskan bahwa seorang mahasiswa memiliki beberapa akses ke dalam sistem, seperti melihat data diri, melihat KHS, Nilai, Jadwal kuliah, melihat dosen dan lain lain.

\section{Use Case Diagram Halaman Dosen}

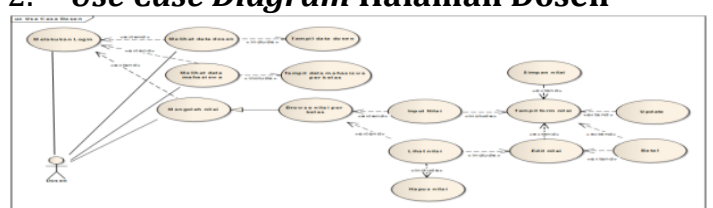

Sumber: (Sastra et al., 2019)

Gambar 2. Use Case Diagram Halaman Dosen
Gambar di atas menjelaskan bahwa seorang dosen dapat mengolah nilai, melihat data mahasiswa, data dosen.

\section{Use case diagram Admin mengelola data} mahasiswa

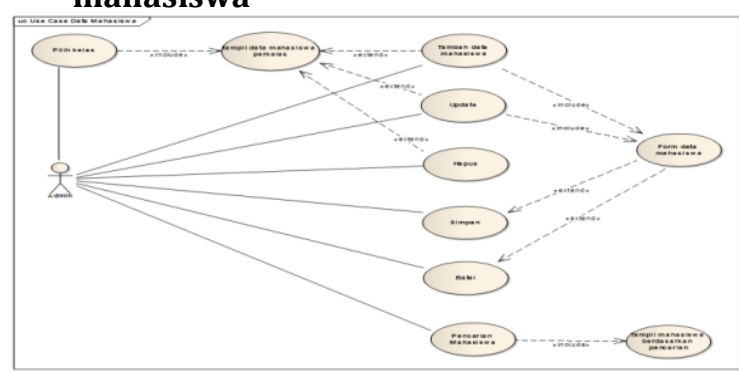

Sumber: (Sastra et al., 2019)

Gambar 3. Use Case Diagram Halaman Admin Mengelola Data Mahasiswa

Gambar di atas menggambarkan bahwa pada halaman admin, seorang admin dapat mengelola data mahasiswa.

4. Use case Diagram Admin Mengelola Data Dosen

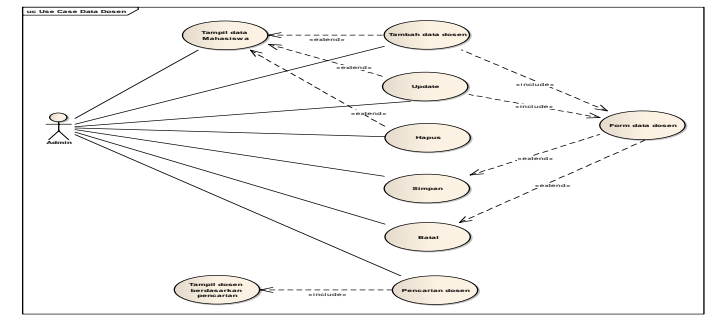

Sumber: (Sastra et al., 2019)

Gambar 4. Use Case Diagram Halaman Admin mengelola Data Dosen

Gambar di atas menggambarkan bahwa seorang admin juga dapat mengelola data dosen

5. Use Case Diagram Admin Mengelola Data Nilai

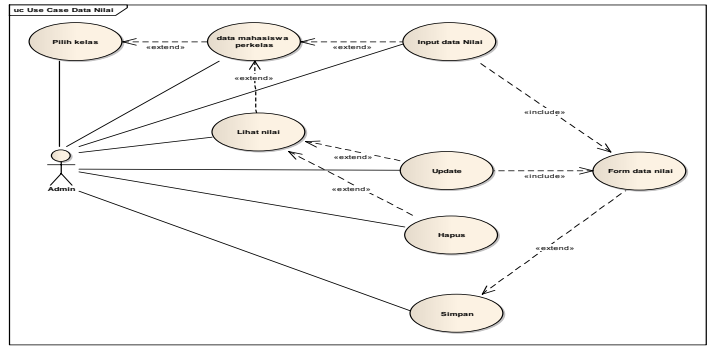

Sumber: (Sastra et al., 2019)

Gambar 5. Use Case Diagram Halaman Admin Mengelola Data Nilai

Gambar di atas menjelaskan bahwa seorang admin memiliki akses untuk mengelola kelas. Selain peneliti merancang use case diagram, 
peneliti juga merancang diagram aktifitas. Rancangan tersebut adalah sebagai berikut:

\section{Activity Diagram Mahasiswa}

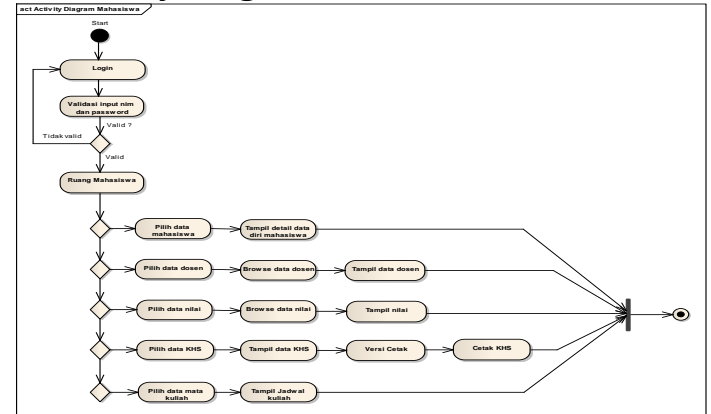

Sumber: (Sastra et al., 2019)

Gambar 6. Activity Diagram Mahasiswa

Rancangan diagram aktifitas di atas adalah menjelaskan aktifitas dari seorang mahasiswa dalam melihat data diri mahasiswa, melihat data dosen, mencetak Kartu Hasil Studi, dan melihat jadwal perkuliahan.

Selain diagram aktifitas seorang mahasiswa, peneliti juga merancangn diagram aktifitas dari dosen, dan diagram aktifitas seorang admin dalam mengelola data mahasiswa, mengelola data dosen, mengelola data kelas, dan lain lain.

\section{Activity Diagram Dosen}

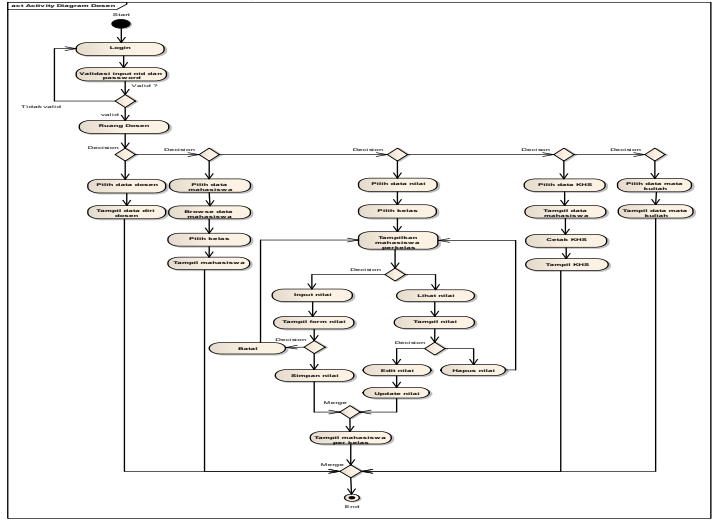

Sumber: (Sastra et al., 2019)

Gambar 7. Activity Diagram Dosen

3. Activity Diagram Admin Mengelola Data Mahasiswa

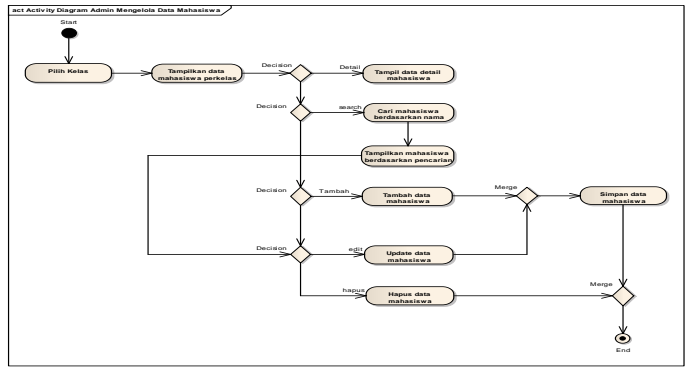

Sumber: (Sastra et al., 2019)
Gambar 8. Activity Diagram Admin Mengelola Data Mahasiswa

Gambaran dari diagram aktifitas di atas menjelaskan kegiatan dari seorang admin dalam mengelola data mahasiswa, yaitu menambah data mahasiswa baru, mengubah data mahasiswa, mencari data mahasiswa, dan menghapus data mahasiswa.

\section{Activity Diagram Admin Mengelola Data} Dosen

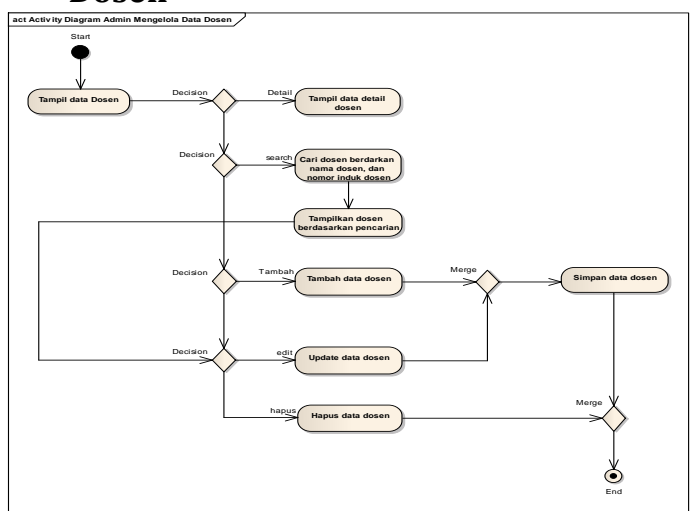

Sumber: (Sastra et al., 2019)

Gambar 9. Activity Diagram Admin Mengelola Data Dosen

Pada gambar diagram aktifitas di atas adalah menjelaskan kegiatan dari seorang admin yang mengelola data dosen. Dari menambah data dosen baru, mengubah data dosen, mencarai data dosen dan menghapus data dosen.

\section{Activity Diagram Admin Mengelola Data} Nilai

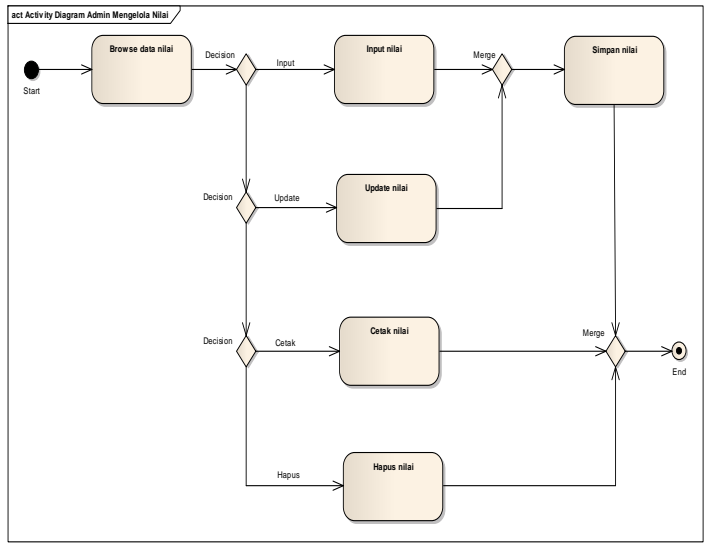

Sumber: (Sastra et al., 2019)

Gambar 10. Activity Diagram Admin Mengelola Data Nilai

Penjelasan dari gambar diagram aktifitas di atas adalah kegiatan dari seorang admin dalam mengelola data nilai dari mahasiswa yag diperoleh dari dosen. 
6. Activity Diagram Admin Mengelola KHS

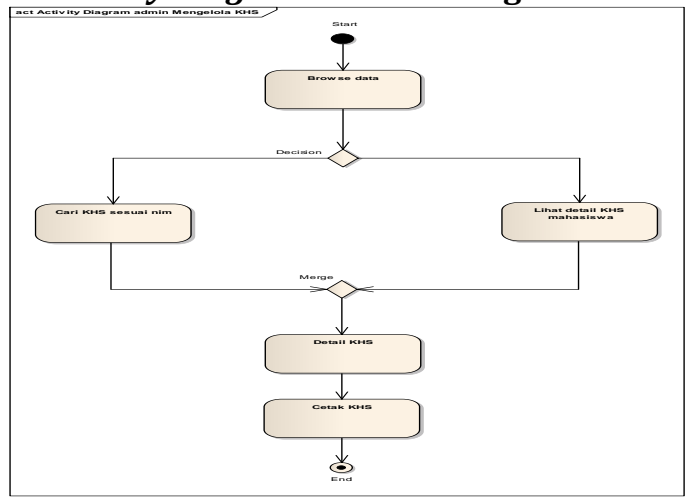

Sumber: (Sastra et al., 2019)

Gambar 11. Activity Diagram Admin Mengelola Data KHS

Diagram aktifitas di atas menjelaskan bahwa seorang admin melakukan pengelolaan terhadap data Kartu Hasil Studi. Setelah peneliti membuat rancangan diagram aktifitas, selanjutnya peneliti merancang kebutuhan yang lain, yaitu database. Mulai dari merancang Entity Relationship Diagram, spesisifkasi file.

Merancang database dimulai dengan merancang Entity Relationship Diagram yaitu seperti berikut:

\section{Entity Relationship Diagram}

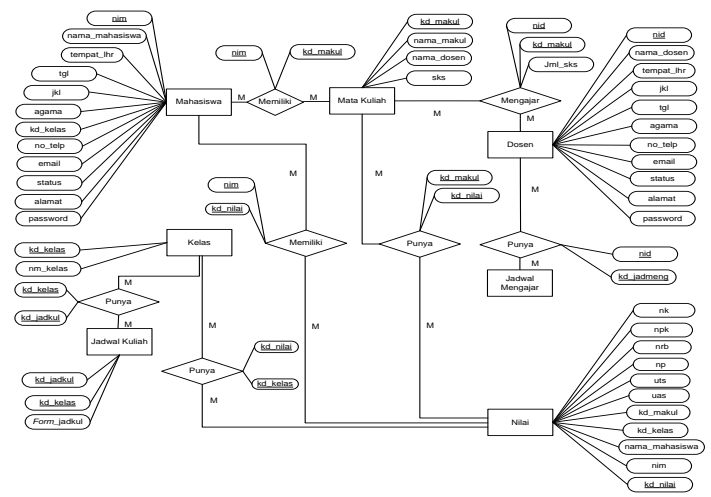

Gambar 12. Entity Relationship Diagram

Gambar Entity Relationship Diagram di atas menggambarkan terdapat tujuh (7) buah entiti yang ketujuh entiti tersebut direlasikan satu sama lain untuk bisa memberikan sebuah informasi secara utuh.

Selanjutnya seteleh Entity Relationship diagram dibuat, peneliti membuat spesifikasi file. Sumbernya adalah dari Entity Relationship Diagram yang bari saja peneliti buat. Berikut rancangannya:

\section{Spesifikasi File Tabel Mahasiswa}

$\begin{array}{ll}\text { Nama Database } & \text { : moriahtesting_db } \\ \text { Nama File } & \text { : Tabel Mahasiswa }\end{array}$

Akronim

Tipe File

Akses File

Panjang Record

Kunci Field

: tbmahasiswa.myd

: File Master

: Random

: 240 Byte

: nim

Tabel 1. Spesifikasi File Tabel Mahasiswa

\begin{tabular}{clllll}
\hline No & $\begin{array}{l}\text { Elemen } \\
\text { Data }\end{array}$ & Nama Field & Type & Size & Ket \\
\hline 1 & NIM & Nim & Varchar & 13 & $P K$ \\
\hline 2 & $\begin{array}{l}\text { Nama } \\
\text { Mahasiswa }\end{array}$ & nama_mahasiswa & Varchar & 35 & \\
\hline 3 & T. Lahir & tempat_lhr & Varchar & 20 & \\
\hline 4 & Tgl Lahir & Tgl & Date & & \\
\hline 5 & J. Kelamin & Jkl & Varchar & 10 & \\
\hline 6 & Agama & Agama & Varchar & 20 \\
\hline 7 & Kode Kelas & kd_kelas & Varchar & 20 & \\
\hline 8 & No Telpon & no_telp & Varchar & 15 & \\
\hline 9 & Email & Email & Varchar & 20 & \\
\hline 10 & Status & Status & Varchar & 10 & \\
\hline 11 & Alamat & Alamat & Varchar & 50 & \\
\hline 12 & Password & password & Varchar & 35 &
\end{tabular}

Spesifikasi File Tabel Dosen

$\begin{array}{ll}\text { Nama Database } & : \text { moriahtesting_db } \\ \text { Nama File } & : \text { Tabel Dosen } \\ \text { Tipe File } & : \text { File Master } \\ \text { Akses File } & : \text { Random } \\ \text { Panjang Record } & : 248 \text { Byte } \\ \text { Kunci Field } & : \text { nid }\end{array}$

Tabel 2. Spesifikasi File Tabel Dosen

\begin{tabular}{cccccc}
\hline No & Elemen Data & Nama Field & Type & $\begin{array}{c}\text { Siz } \\
\text { e }\end{array}$ & Kete \\
\hline 1 & NID & Nid & Integer & 20 & $\begin{array}{c}\text { Primary } \\
\text { Key }\end{array}$ \\
& & & & & \\
\hline 2 & Nama Dosen & nama_dosen & Varchar & 35 & \\
\hline 3 & T. Lahir & tempat_lhr & Varchar & 20 & \\
\hline 4 & Tgl Lahir & Tgl & Date & & \\
\hline 5 & J. Kelamin & Jkl & Varchar & 10 & \\
\hline 6 & Agama & Agama & Varchar & 15 & \\
\hline 7 & No Telpon & no_telp & Varchar & 12 & \\
\hline 8 & Email & Email & Varchar & 20 & \\
\hline 9 & Status & Status & Varchar & 8 & \\
\hline 10 & Alamat & Alamat & Varchar & 50 & \\
\hline 11 & Password & Password & Varchar & 35 & \\
\hline 7 & & & &
\end{tabular}

Spesifikasi File Tabel Admin

Nama Database

Nama File

: moriahtesting_db

Akronim

: Tabel Admin

Tipe File

: admin.myd

Akses File

: File Master

Panjang Record

: Random

Kunci Field

: 122 Byte

: username 
Tabel 3. Spesifikasi File Tabel Admin

\begin{tabular}{cccccc}
\hline No & $\begin{array}{c}\text { Elemen } \\
\text { Data }\end{array}$ & Nama Field & Type & Size & Keterangan \\
\hline 1 & Username & username & Varchar & 20 & $\begin{array}{c}\text { Primary } \\
\text { Key }\end{array}$ \\
\hline 2 & Password & password & Varchar & 30 & \\
\hline 3 & $\begin{array}{c}\text { Nama } \\
\text { Admin }\end{array}$ & nama_admn & Varchar & 30 & \\
\hline 4 & $\begin{array}{c}\text { Email } \\
\text { Admin }\end{array}$ & email_admin & Varchar & 30 & \\
\hline 5 & Telp & Telp & Varchar & 12 & \\
\hline
\end{tabular}

\section{Spesifikasi File Tabel Nilai}

Nama Database : : moriahtesting_db

Nama File : : Tabel Nilai

Akronim : tblnilai.myd

Tipe File : File Transaksi

Akses File : Random

Panjang Record : 95 Byte

Kunci Field : kd_nilai

Tabel 4. Spesifikasi File Tabel Nilai

\begin{tabular}{clcccc}
\hline No & Elemen Data & Nama Field & Type & Size & Ket \\
\hline 1 & Kode Nilai & kd_nilai & Int & 5 & $P K$ \\
\hline 2 & Nim & nim & Var & 10 & $F K$ \\
\hline 3 & Nama Mhs & nama_mhs & Var & 50 & \\
\hline 4 & Kode Kelas & kd_kelas & Var & 10 & $F K$ \\
\hline 5 & Kode Makul & kd_makul & Var & 5 & $F K$ \\
\hline 6 & $\begin{array}{l}\text { Nilai } \\
\text { Kehadiran }\end{array}$ & nk & Int & 3 & \\
\hline 7 & $\begin{array}{l}\text { Nilai } \\
\text { Partisipasi/K } \\
\text { eaktifan }\end{array}$ & npk & Int & 3 & \\
\hline 8 & $\begin{array}{l}\text { Nilai Resensi } \\
\text { Buku }\end{array}$ & nrb & Int & 3 & \\
\hline 9 & $\begin{array}{l}\text { Nilai } \\
\text { Presentasi }\end{array}$ & np & Int & 3 & \\
\hline 10 & Nilai UTS & uts & Int & 3 & \\
\hline 11 & Nilai UAS & uas & Int & 3 & \\
\hline
\end{tabular}

Setelah spesifikasi file selesai dibuat, selanjutnya peneliti membuat arsitektur dari software yang akan dibuat. Seperti berikut:

\section{Component Diagram}

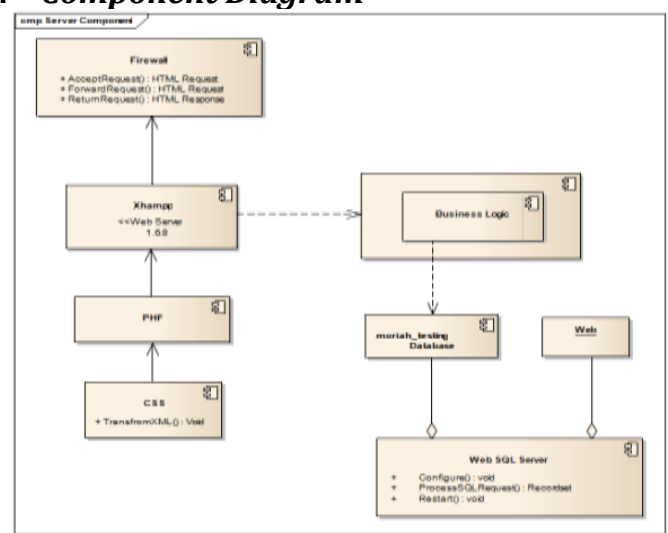

Sumber: (Sastra et al., 2019)

Gambar 13. Component Diagram

\section{Deployment Diagram}

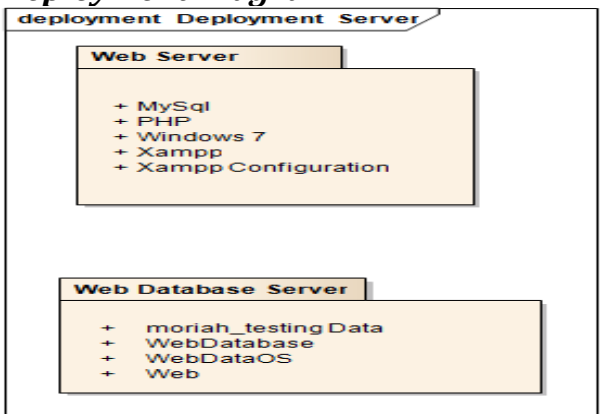

Sumber: (Sastra et al., 2019)

Gambar 14. Deployment Diagram

Selanjutnya peneliti membuat rancangan user interface seperti berikut:

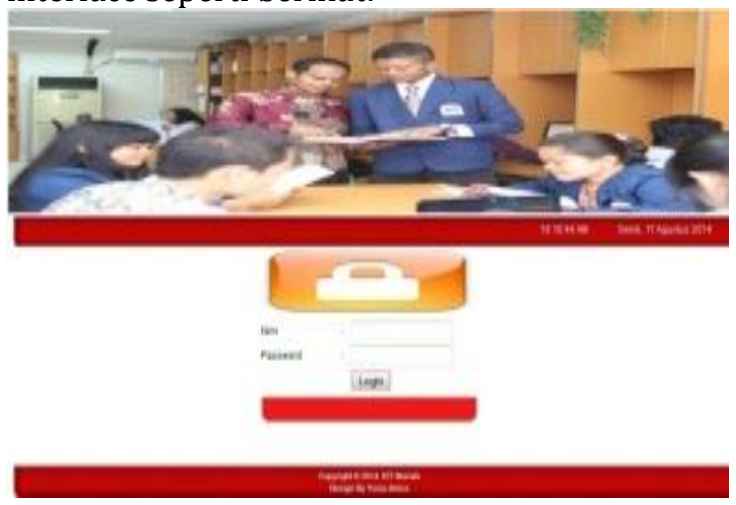

Sumber: (Sastra et al., 2019)

Gambar 15. Tampil Form Login Mahasiswa

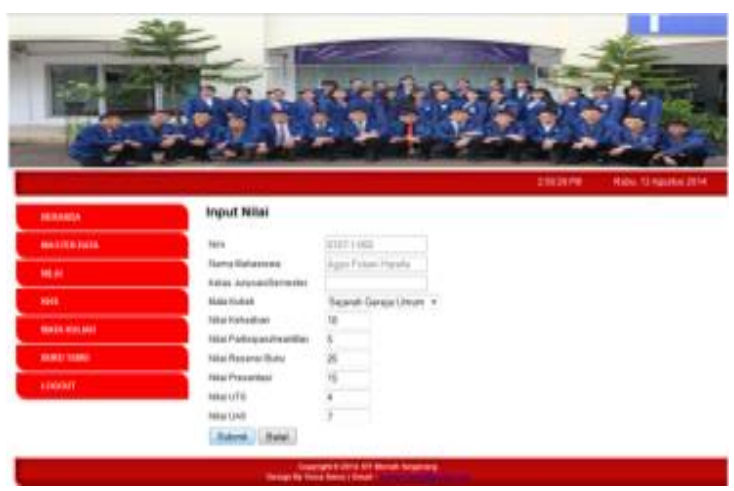

Sumber: (Sastra et al., 2019)

Gambar 16. Tampil Form Input Nilai

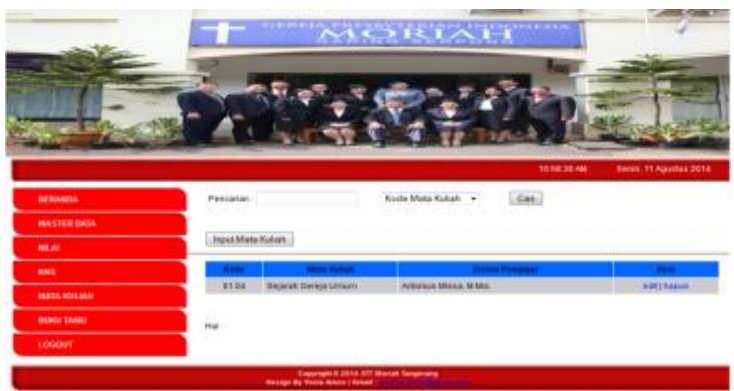

Sumber: (Sastra et al., 2019)

Gambar 17. Tampil Form Input Mata Kuliah 


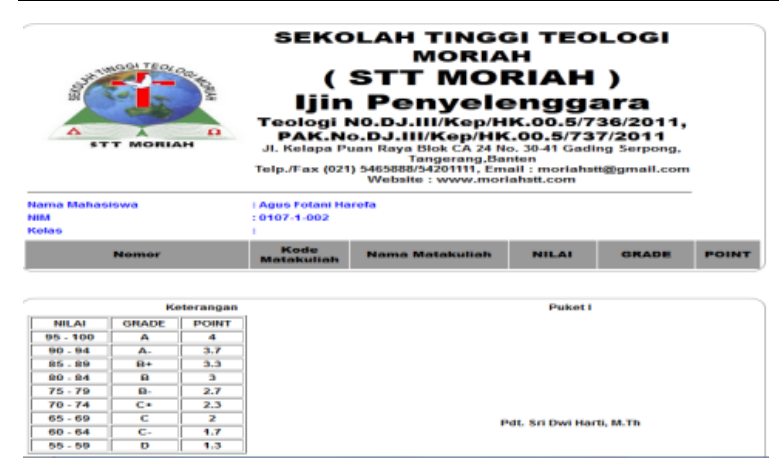

Sumber: (Sastra et al., 2019)

Gambar 18. Tampil Form KHS

\section{KESIMPULAN}

Berdasarkan uraian dan penjelasan dari pmebahasan diatas, maka penulis dapat mengambil suatu kesimpulan yaitu untuk efektifitas dan efisiensi dalam proses tambah, ubah, cari, dan hapus data pada STT Moriah dapat di selesaikan atau di tangani dengan dibuatkan sistem informasi akademik. Sistem ini juga menjadi solusi terhadap sering terjadinya kehilangan data karena tercecer.

\section{REFERENSI}

Fathansyah. (2012). Basis Data. Bandung: Informatika.

Kadir, A. (2009). Membuat Aplikasi Web dengan PHP + Database MySQL. Yogyakarta: Andi.

Kesuma, C., \& Rahmawati, L. (2017). Sistem Informasi Akademik Berbasis Web Pada Purnama 2 Banyumas. Sistem Informasi Akademi Berbasis Web Pada SMK Purnama 2 Banyumas, 7(3), 142-150.

Liatmaja, R., \& Wardati, I. U. (2013). Sistem Informasi Akademik Berbasis Web Pada Lembaga Bimbingan Belajar Be Excellent Pacitan Rizka Liatmaja, Indah Uly Wardati. Indonesia Jurnal on Networking and Security, 2(2), 58-63.

Mahfudz, I. (2013). Sistem Informasi Penjualan Berbasis Web. 5(2), 66-73.

Nawawi, I., Abdilah, A., \& Nurajijah. (2018). Sistem Monitoring Barang Cetak Berbasis Web Menggunakan Model Waterfall. Inti Nusa Mandiri, 4(1), 1-14.

Nuraini, S. H., Purnama, B. E., \& Tj, T. I. (2013). Pembuatan Sistem Informasi Kartu Rencana Studi (KRS) Dan Kartu Hasil Studi (KHS) Pada Program Studi Teknik Informatika Universitas Surakarta. Ijns 16, 10,1-7. Retrieved from http://ijns.org
Rosa A. S, \& Shalahudin, M. (2014). Rekayasa Perangkat Lunak: Terstruktur dan berorientasi objek. Bandung: Informatika.

Sastra, R., Nawawi, I., \& Abdilah, A. (2019). Laporan Akhir Penelitian Sistem Informasi Akademik Sekolah Tinggi Teologi Moriah.

Sutabri, T. (2012). Analisis Sistem Informasi. Jogjakarta: Penerbit Andi. 